\title{
Mustard (Sinapis alba) Seed Meal Suppresses Weeds in Container-grown Ornamentals
}

\author{
Rick A. Boydston ${ }^{1}$ and Treva Anderson \\ U.S. Department of Agriculture-Agricultural Research Service, Vegetable \\ and Forage Crops Research, 24106 North Bunn Road, Prosser, WA 99350
}

\author{
Steven F. Vaughn \\ U.S. Department of Agriculture-Agricultural Research Service, National \\ Center for Agricultural Utilization Research, 1815 North University Street, \\ Peoria, IL 61604
}

Additional index words. containers, natural products, weed control

\begin{abstract}
Mustard seed meal is a byproduct of mustard (Sinapis alba L.) grown for oil production. Developing new uses for mustard seed meal could increase the profitability of growing mustard. Seed meal of mustard, var. 'IdaGold', was applied to the soil surface to evaluate its effect on several common weeds in container-grown ornamentals. Mustard seed meal applied to the soil surface of containers at 113, 225, and $450 \mathrm{~g} \cdot \mathrm{m}^{-2}$ reduced the number of annual bluegrass (Poa annua $\mathrm{L}$.) seedlings by $60 \%$, $86 \%$, and $98 \%$, respectively, and the number of common chickweed (Stellaria media $\mathrm{L}$.) seedlings by $61 \%, 74 \%$, and $73 \%$, respectively, at 8 weeks after treatment (WAT). Mustard seed meal applied to the soil surface after transplanting Rosa L. hybrid, var. 'Red Sunblaze', Phlox paniculata L., var. 'Franz Schubert', and Coreopsis auriculata L., var. 'Nana' did not injure or affect the flowering or growth of ornamentals. In separate experiments, mustard seed meal applied at $225 \mathrm{~g} \cdot \mathrm{m}^{-2}$ to the soil surface reduced the number of emerged seedlings and fresh weight of creeping woodsorrel (Oxalis corniculata) $90 \%$ and $95 \%$, respectively, at $8 \mathrm{WAT}$. Mustard seed meal applied at $450 \mathrm{~g} \cdot \mathrm{m}^{-2}$ completely prevented woodsorrel emergence at 8 WAT. Mustard seed meal applied postemergence to established liverwort (Marchantia polymorpha $L$.) at 113, 225, and 450 g. $\mathbf{m}^{-2}$ did not injure container-grown Pulsatilla vulgaris Mill., var. 'Heiler Hybrids Mixed' up to 6 WAT and controlled liverwort from $83 \%$ to $97 \%$ at 6 WAT. Weed suppression with mustard seed meal generally increased as rate increased from 113 to $450 \mathrm{~g} \cdot \mathrm{m}^{-2}$. Mustard seed meal may be useful for selective suppression of annual weeds when applied to the soil surface of container-grown transplanted ornamentals.
\end{abstract}

The use of herbicides in container-grown ornamentals is often limited as a result of the lack of registered products for use in greenhouses and the difficulty in assuring crop safety on numerous species grown in ornamental nurseries. Typically, many producers hand-weed containers to ensure maximum growth of ornamentals and to keep weeds from lowering the value of the crop. The use of products derived from natural sources to control pests is appealing, and developing new uses for mustard (Sinapis alba) seed meal (MSM) and other byproducts of the expanding biofuels industry may increase the

\footnotetext{
Received for publication 28 Nov. 2007. Accepted for publication 6 Jan. 2008.

We thank NW Horticulture Co., 951 Allison Road, Mabton, WA 98935 for supplying ornamental plants and potting soil. We also thank McKay Seed, 2945 Road N NE, Moses Lake, WA 98837 for supplying mustard seed meal; and Big River Resources, LLC, 15210 103rd Street, West Burlington, IA 52655 for supplying corn dried distillers grains.

${ }^{1}$ To whom reprint requests should be addressed; e-mail rick.boydston@ars.usda.gov
}

profitability of biofuel production (Boydston et al., 2008; Miller, 2006).

Corn gluten meal, a byproduct from corn wet-milling, has been used as a natural herbicide in turf and other crops (Liu and Christians, 1997; Liu et al., 1994; McDade and Christians, 2001; Nonnecke and Christians, 1993). Dried distiller grains with solubles (DDGS) are a byproduct of ethanol produced from corn that inhibits growth of several weeds and ornamentals when applied as a surface mulch or soil amendment (Boydston et al., 2008).

Mustard is grown for oil and as a condiment. After oil extraction, MSM is left as a byproduct. MSM contains glucosinolates (GLS) that typically undergo enzymatic hydrolysis to isothiocyanates, thiocyanate $\left(\mathrm{SCN}^{-}\right)$, nitriles, and other compounds when added to moist soil (Borek and Morra, 2005; Brown et al., 1991). Several breakdown products of GLS have pesticidal properties, including weed suppression (Al-Khatib and Boydston, 1999; Borek and Morra, 2005; Boydston and Al-Khatib, 2006; Brown and Morra, 1995; Oleszek, 1987; Oleszek et al., 1994; Vaughn and Boydston, 1997). In a 2-year study, MSM applied at $64.4 \mathrm{~g} \cdot \mathrm{m}^{-2}$ to strawberry reduced weeding time in 1 year but had no effect on weeding time the other year (Miller, 2006). The predominant GLS in mustard seed is 4-hyroxybenzyl glucosinolate or sinalbin, which ultimately yields $\mathrm{SCN}^{-}$ that may be partly responsible for phytotoxic effects often observed with MSM (Borek and Morra, 2005; Daxenbichler et al., 1991). Seed meal of meadowfoam (Limnanthes alba Hartw. ex Benth), another oil seed crop containing GLS, has been shown to suppress liverwort (Marchantia polymorpha), a troublesome weed in nursery crops and greenhouses, and inhibited radicle elongation of velvetleaf (Abutilon theophrasti Medicus) and wheat (Triticum aestivum L.) (Svenson and Deuel, 2000; Vaughn et al., 1996).

MSM applied to the soil suppressed emergence of several annual weeds in studies by Ascard and Johansson (1991). MSM applied at $168 \mathrm{~g} \cdot \mathrm{m}^{-2}$ and tarped controlled annual bluegrass (Poa annua), common chickweed (Stellaria media), broadleaf plantain (Plantago major L.), and white clover (Trifolium repens L.) $73 \%$ or greater in greenhouse studies (Earlywine et al., 2007). However, untarped MSM treatments controlled weeds less consistently. In studies by Rice et al. (2007), early season redroot pigweed (Amaranthus retroflexus L.) biomass was $72 \%$ to 93\% lower and common lambsquarters biomass (Chenopodium album L.) $87 \%$ to $99 \%$ less in soil amended with $1 \%$ to $3 \%(\mathrm{wt} / \mathrm{wt}$ ) Oriental mustard [Brassica juncea (L.) Czern.] seed meal relative to nontreated soil. However, weed control was short-lived. $S$. alba seed meal applied at $200 \mathrm{~g} \cdot \mathrm{m}^{-2}$ reduced weed emergence and biomass $95 \%$ and $88 \%$ in strawberries compared with nontreated control (Brown et al., 2006). Canola (B. napus L.) and Oriental mustard (B. juncea) seed meals were less herbicidal than $S$. alba seed meal when applied at similar rates. MSM also contains $\approx 5 \%$ nitrogen, making it appealing as a potential fertilizer supplement (Borek and Morra, 2005).

DDGS controlled weeds selectively when surface-applied to container-grown ornamentals but, when mixed into potting soil, injured transplanted ornamentals (Boydston et al., in press). Likewise, surface-applied MSM may control weeds in container-grown ornamentals without injuring the crop. This research evaluated the response of four common nursery weeds and four transplanted perennial ornamentals to several rates of MSM applied to the soil surface.

\section{Materials and Methods}

Seed meal. MSM (S. alba, var. 'IdaGold') was obtained locally (McKay Seed Co., Moses Lake, WA). Mustard seed was coldpressed and extruded flakes were run through a hammer mill to obtain a more uniform granular product. Potting mix used in all studies was obtained from a commercial wholesale nursery and greenhouse operator (Northwest Horticulture, Mabton, WA) and consisted of $40 \%$ pine bark, $40 \%$ peatmoss, and $20 \%$ pumice (by volume) with $\mathrm{pH} 5.6$. 
Glucosinolate content of MSM was determined by a modification of a highperformance liquid chromatography (HPLC) method developed by Betz and Fox (1994). Defatted seed meal samples (5.0 g) were added to $200 \mathrm{~mL}$ boiling $70 \%$ (v/v) methanol $(\mathrm{MeOH})$ while stirring for $15 \mathrm{~min}$, cooled, and then filtered through Whatman No. 2 filter paper (Whatman, Florham Park, NJ). The marc was washed twice with $50-\mathrm{mL}$ aliquots of $70 \% \mathrm{MeOH}$. The resulting extract was concentrated to 5 to $10 \mathrm{~mL}$ by rotoevaporation and diluted to $25 \mathrm{~mL}$ to form a working solution. The extract was run on a Finnegan Thermoquest P4000 HPLC system (San Jose, CA) using a $\mathrm{C}_{18}$ column $(250 \mathrm{~mm} \times$ $4.6 \mathrm{~mm}$; RP-18, $5 \mu$, Licrosorb; Alltech, Deerfield, IL). Peaks were detected with a Finnegan Thermoquest P6000 photodiode array detector set at $237 \mathrm{~nm}$. The initial mobile phase conditions were $12 \%$ methanol $/ 88 \%$ aqueous $0.005 \mathrm{M}$ THS at a flow rate of $1 \mathrm{~mL} / \mathrm{min}$. The binary gradient was developed to $70 \%$ methanol $/ 30 \%$ aqueous $0.005 \mathrm{M}$ THS for $20 \mathrm{~min}$ and held at these conditions for an additional $15 \mathrm{~min}$. Sinalbin quantitation was determined from a standard curve prepared from purified sinalbin previously isolated from defatted white mustard seed meal using the method of Vaughn and Berhow (2005). Each sample was run in triplicate and repeated once.

Effect of mustard seed meal on common chickweed (S. media) and annual bluegrass (P. annua) in transplanted ornamentals. One 2.5-cm plug each of coreopsis (Coreopsis auriculata, var. 'Nana'), rose (Rosa hybrid, var. 'Red Sunblaze'), and phlox (Phlox paniculata, var. 'Franz Schubert') were transplanted into 7.5-L containers filled with potting mix. After transplanting, 20 seeds each of annual bluegrass and common chickweed were seeded on the surface of each pot and lightly covered with potting mix. MSM was then applied evenly over the surface of each pot at $0,113,225$, and $450 \mathrm{~g} \cdot \mathrm{m}^{-2}$ and then sprinkled lightly with $0.33 \mathrm{~cm}$ water. After treatment, containers were placed outdoors under $65 \%$ shadecloth and watered daily as needed.

The number of emerged weed seedlings and weed height were determined at 2, 4, 6, and 8 weeks after planting (WAP). Weeds were clipped at the soil surface at $8 \mathrm{WAP}$ and weighed. Injury to ornamental plants, plant height, and number of blooms were evaluated at $2,4,6$, and 8 weeks after transplanting (WAT). Injury was rated on a scale of $0=$ no injury to $10=$ dead. Treatments were replicated five times in a completely randomized design and the experiment was repeated.

Effect of mustard seed meal on creeping woodsorrel (Oxalis corniculata L.). Twentyfive seeds of creeping woodsorrel were planted $1.5 \mathrm{~mm}$ deep in 0.5 -L pots filled with potting mix. MSM was applied at 0, 113, 225 , and $450 \mathrm{~g} \cdot \mathrm{m}^{-2}$ to the soil surface and lightly watered. In addition, a treatment of DDGS was applied at $225 \mathrm{~g} \cdot \mathrm{m}^{-2}$. DDGS were obtained from a commercial ethanol plant (Big River Resources LLC, West Burlington, IA). Pots were placed in a greenhouse set at $23{ }^{\circ} \mathrm{C}$ with a 14-h photoperiod and watered daily as needed. The number of creeping woodsorrel seedlings emerged and plant height were determined at 2, 4, and 6 WAP. Plants were clipped at the soil surface and weighed at 6 WAP. Treatments were replicated five times in a completely randomized design and the experiment was repeated.

Effect of mustard seed meal on liverwort (Marchantia polymorpha) and pasque flower (Pulsatilla vulgaris). Pasque flower var. 'Heiler Hybrids Mixed' naturally infested with liverwort was grown in 4-L containers in a greenhouse. MSM was applied at 0, 113, 225 , and $450 \mathrm{~g} \cdot \mathrm{m}^{-2}$ when liverwort was 1 to $2.5 \mathrm{~cm}$ thick and covered the entire soil surface of each pot. Pasque flower averaged $20 \mathrm{~cm}$ tall and had flower buds at the time mustard meal was applied. MSM application was directed onto liverwort thalli by hand and lightly watered with a misting nozzle being careful not to wash the seed meal off the foliage. Pots were placed in a greenhouse set at $23{ }^{\circ} \mathrm{C}$ with a 16 -h photoperiod and watered daily as needed. Liverwort control and pasque flower injury were recorded at 2, 4, 6, and 8 WAP. Liverwort control was estimated by determining the percent of the soil surface occupied with live liverwort foliage. Pasque flower injury was rated on a scale of $0=$ no injury to $10=\mathrm{dead}$. Treatments were replicated five times in a completely randomized design and the experiment was repeated three times.

Data from all studies were subjected to analysis of variance (ANOVA) and treatment means separated using the Fisher's protected least significant difference test at $P=0.05$ level. Data from separate experiments were combined for analysis when ANOVA indicated that differences between experiments were not significant.

\section{Results}

MSM contained $23.82 \pm 0.09 \mathrm{mg} \cdot \mathrm{g}^{-1}$ dry wt sinalbin. Sinalbin levels in white mustard seed can range from zero to $68 \mathrm{mg} \cdot \mathrm{g}^{-1}$ depending on variety (Drost et al., 1999). Borek and Morra (2005) reported $64 \mathrm{mg} \cdot \mathrm{g}^{-1}$ sinalbin in MSM from the same cultivar, 'IdaGold', in previous work. Although not investigated in this study, sinalbin degradation products such as thiocyanate ion may be responsible for herbicidal activity of MSM (Borek and Morra, 2005).

Effect of mustard seed meal on common chickweed and annual bluegrass in transplanted ornamentals. MSM applied to the soil surface at 113,225 , or $450 \mathrm{~g} \cdot \mathrm{m}^{-2}$ immediately after transplanting ornamentals did not affect the growth or flowering of transplanted rose, phlox or coreopsis from 2 to 8 WAP (Table 1). Although plant number and

Table 1. Height, number of flowers and flower buds, and phytotoxicity rating on rose, phlox, and coreopsis 8 weeks after transplanting into potting soil amended with surface-applied mustard seed meal at three rates.

\begin{tabular}{|c|c|c|c|c|c|c|c|c|c|}
\hline \multirow[b]{2}{*}{$\begin{array}{l}\text { Mustard seed } \\
\text { meal rate }\left(\mathrm{g} \cdot \mathrm{m}^{-2}\right)\end{array}$} & \multicolumn{3}{|c|}{ Rose Red Sunblaze } & \multicolumn{3}{|c|}{ Phlox Franz Schubert } & \multicolumn{3}{|c|}{ Coreopsis Nana } \\
\hline & $\begin{array}{c}\mathrm{Ht} \\
(\mathrm{cm})\end{array}$ & $\begin{array}{c}\text { Flowers and } \\
\text { buds (no./pot) }\end{array}$ & $\begin{array}{c}\text { Phytotoxicity } \\
(0-10)\end{array}$ & $\begin{array}{l}\mathrm{Ht} \\
(\mathrm{cm})\end{array}$ & $\begin{array}{c}\text { Flowers and } \\
\text { buds (no./pot) }\end{array}$ & $\begin{array}{c}\text { Phytotoxicity } \\
(0-10)\end{array}$ & $\begin{array}{l}\mathrm{Ht} \\
(\mathrm{cm})\end{array}$ & $\begin{array}{c}\text { Flowers and } \\
\text { buds (no./pot) }\end{array}$ & $\begin{array}{c}\text { Phytotoxicity } \\
(0-10)\end{array}$ \\
\hline 0 & $12.4^{1}$ & 2.9 & 0 & 20.2 & 32 & 0 & 8.8 & 1.5 & 0 \\
\hline 113 & 11.8 & 3.1 & 0 & 20.3 & 11 & 0 & 8.6 & 3.7 & 0 \\
\hline 225 & 11.8 & 3.1 & 0 & 20.8 & 20 & 0 & 10.5 & 2.5 & 0 \\
\hline 450 & 10.9 & 2.9 & 0 & 18.7 & 14 & 0 & 10.2 & 3.4 & 0 \\
\hline LSD $(0.05)$ & NS & NS & NS & NS & NS & NS & NS & NS & NS \\
\hline
\end{tabular}

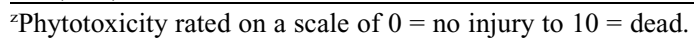

${ }^{\text {Ns }}$ Nonsignificant.

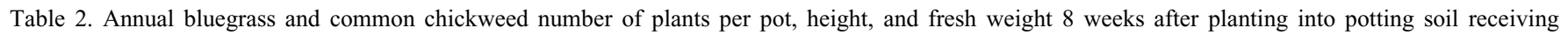
surface-applied mustard seed meal.

\begin{tabular}{|c|c|c|c|c|c|c|}
\hline \multirow[b]{2}{*}{$\begin{array}{l}\text { Mustard seed } \\
\text { meal rate }\left(\mathrm{g} \cdot \mathrm{m}^{-2}\right)\end{array}$} & \multicolumn{3}{|c|}{ Annual bluegrass } & \multicolumn{3}{|c|}{ Common chickweed } \\
\hline & $\begin{array}{c}\text { Number of } \\
\text { seedlings (no./pot) }\end{array}$ & $\mathrm{Ht}(\mathrm{cm})$ & $\begin{array}{c}\text { Fresh } \\
\text { wt (g/pot) }\end{array}$ & $\begin{array}{c}\text { Number of } \\
\text { seedlings (no./pot) }\end{array}$ & $\mathrm{Ht}(\mathrm{cm})$ & $\begin{array}{c}\text { Fresh } \\
\text { wt (g/pot) }\end{array}$ \\
\hline 0 & 12.4 & 15.6 & 3.1 & 7.7 & 9.9 & 11.0 \\
\hline 113 & 4.9 & 14.0 & 1.1 & 3.0 & 7.5 & 3.3 \\
\hline 225 & 1.7 & 8.4 & 0.4 & 2.0 & 8.2 & 2.8 \\
\hline 450 & 0.2 & 1.8 & 0.02 & 2.1 & 4.7 & 1.4 \\
\hline LSD $(0.05)$ & 2.7 & 2.9 & 0.8 & 1.7 & 2.1 & 2.8 \\
\hline
\end{tabular}


height data were collected every 2 weeks, only the final data collected at 6 or 8 WAT is presented. No visual phytotoxicity symptoms were observed on any of the perennial ornamentals tested throughout the 8-week period after MSM application.

MSM inhibited emergence and reduced height and final fresh weight of annual bluegrass and common chickweed at all rates tested (Table 2). Most annual bluegrass emerged within the first week after planting (data not shown). All rates of MSM greatly decreased the number of annual bluegrass per container. The 225 and $450-\mathrm{g} \cdot \mathrm{m}^{-2}$ rates reduced seedling numbers by $86 \%$ and $98 \%$, respectively, and fresh weight $86 \%$ and $99 \%$, respectively, at 8 WAT (Table 2). Seedlings that emerged in pots treated with MSM were shorter and slower-growing than in nontreated pots and often died soon after emergence.

Most chickweed germinated within a 2week period after planting (data not shown). All rates of MSM tested reduced the number of common chickweed seedlings per container and final plant weight per pot at 8 WAT (Table 2). Final plant weight of common chickweed was $13 \%$ to $30 \%$ of that in nontreated checks at 8 WAT. MSM applied at $450 \mathrm{~g} \cdot \mathrm{m}^{-2}$ reduced final common chickweed height $53 \%$ compared with nontreated checks, whereas $113 \mathrm{~g} \cdot \mathrm{m}^{-2}$ reduced chickweed height only $24 \%$ (Table 2 ).

Effect of mustard seed meal on creeping woodsorrel. MSM inhibited emergence and growth of creeping woodsorrel at all rates tested (Table 3). Creeping woodsorrel that emerged in soil amended with MSM were chlorotic and shorter than seedlings grown in nonamended potting soil and most emerging seedlings died. MSM applied at $113 \mathrm{~g} \cdot \mathrm{m}^{-2}$ reduced the number of woodsorrel seedlings from $14.8 /$ pot to $4.1 /$ pot at $6 \mathrm{WAT}$ and at 225 and $450 \mathrm{~g} \cdot \mathrm{m}^{-2}$ reduced woodsorrel to 1.4 and 0.1 seedlings per container, respectively. Final fresh weight of creeping woodsorrel at 6 WAT was $33 \%, 5 \%$, and $0 \%$ of the nontreated checks with 113,225 , and $450 \mathrm{~g} \cdot \mathrm{m}^{-2}$ MSM, respectively (Table 3 ). DDGS at 225 $\mathrm{g} \cdot \mathrm{m}^{-2}$ reduced the number of creeping woodsorrel emergence $25 \%$, but plant height and fresh weight at 6 WAT was similar to nontreated checks (Table 3 ).

Effect of mustard seed meal on liverwort and pasque flower. MSM applied to thalli of actively growing liverwort caused necrosis of tissue within 2 to $3 \mathrm{~d}$ after application and most liverwort thalli with seed meal on it eventually died (Table 4). Fungal growth developed on liverwort thalli covered with mustard meal $\approx 1$ week after application. No phytotoxic symptoms were observed on pasque flower, which was in full bloom $\approx 1$ week after mustard meal was applied (Table 4).

\section{Discussion}

MSM applied to the soil surface did not injure container grown rose, phlox, coreopsis, and pasque flower up to 8 weeks after application. MSM applied at rates of 113 to
Table 3. Effect of surface-applied mustard seed meal and dried distiller grains (DDGS) on creeping woodsorrel number of seedlings per pot, height, and fresh weight 8 weeks after seeding.

\begin{tabular}{lcccr}
\hline & & \multicolumn{3}{c}{ Creeping woodsorrel } \\
\cline { 3 - 5 } Treatment & $\begin{array}{c}\text { Rate } \\
\left(\mathrm{g} \cdot \mathrm{m}^{-2}\right)\end{array}$ & $\begin{array}{c}\text { Number of } \\
\text { seedlings (no./pot) }\end{array}$ & $\begin{array}{c}\text { Ht } \\
(\mathrm{cm})\end{array}$ & $\begin{array}{c}\text { Fresh } \\
\text { wt }(\mathrm{g} / \mathrm{pot})\end{array}$ \\
\hline None & - & 14.8 & 10.8 & 22.3 \\
Mustard seed meal & 113 & 4.1 & 4.7 & 7.2 \\
Mustard seed meal & 225 & 1.4 & 2.1 & 1.2 \\
Mustard seed meal & 450 & 0.1 & 0.0 & 0.0 \\
DDGS & 225 & 11.1 & 10.6 & 22.5 \\
LSD $(0.05)$ & & 2.8 & 1.9 & 4.7 \\
\hline
\end{tabular}

Table 4. Phytotoxicity of foliar-applied mustard seed meal on liverwort and Pulsatilla vulgaris, var. Heiler Hybrids Mixed grown in the greenhouse.

\begin{tabular}{|c|c|c|c|c|}
\hline \multirow{3}{*}{$\begin{array}{l}\text { Mustard seed } \\
\text { meal rate }\left(\mathrm{g} \cdot \mathrm{m}^{-2}\right)\end{array}$} & \multicolumn{2}{|c|}{ Liverwort } & \multicolumn{2}{|c|}{ Pasque flower } \\
\hline & Control (4 WAT) & Control (6 WAT) & Injury (4 WAT) & Injury (8 WAT) \\
\hline & \multicolumn{2}{|c|}{$(\%)$} & \multicolumn{2}{|c|}{$(\%)$} \\
\hline 0 & - & - & - & - \\
\hline 113 & 83 & 83 & 0 & 0 \\
\hline 225 & 93 & 95 & 0 & 0 \\
\hline 450 & 96 & 97 & 0 & 0 \\
\hline LSD $(0.05)$ & 7.2 & 11.6 & NS & NS \\
\hline
\end{tabular}

WAT, weeks after treatment.

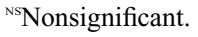

$450 \mathrm{~g} \cdot \mathrm{m}^{-2}$ reduced annual bluegrass, common chickweed, and creeping woodsorrel emergence and growth. Weed suppression generally increased as MSM rate increased. MSM applied to actively growing liverwort killed many plants and suppressed growth of remaining plants.

Some weed seedlings emerged after surface treatment with MSM indicating that uniform coverage and placement of seed meals near germinating weed seedlings may be important for maximum efficacy. Typically, MSM obtained from pressing mustard seed is in the form of large irregular flakes, which would require processing to a smaller, more easily spreadable product as was used in this study (Fig. 1). Soil disturbance after surface treatment with MSM would likely reduce weed control by creating areas of free of seed meal or its breakdown products with herbicidal activity. Thiocyanate ion is reportedly released from MSM in the presence of myrosinase enzyme and water and may be partially responsible for the observed phytotoxicity to small weeds (Borek and Morra, 2005). Thiocyanate ion is water-soluble and is likely carried to the vicinity of shallow germinating weed seedlings by watering. The tolerance of transplanted ornamentals to surface-applied MSM is likely the result of both the placement of MSM above the root zone and the larger size and stage of growth of the ornamental plants relative to the small germinating weed seedlings when exposed to MSM.

MSM rates used in these studies were generally lower than rates of corn gluten meal or DDGS required for weed suppression in previous research (Bingaman and Christians, 1995; Boydston et al., 2008). However, these rates of 225 to $450 \mathrm{~g} \cdot \mathrm{m}^{-2}$ are still 10 - to 20 -fold higher than typical granular herbicides often used in nurseries, which could potentially limit MSM use. Currently, mustard is not widely grown and MSM availabil-

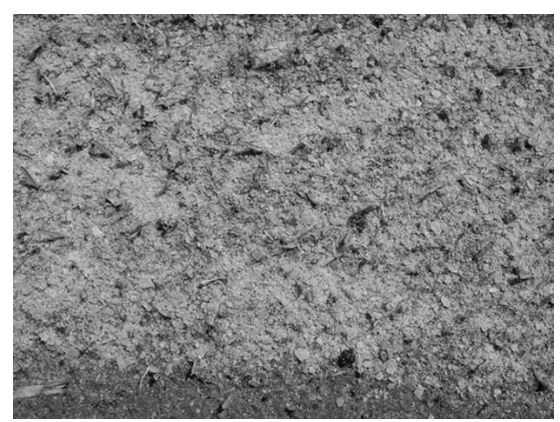

Fig. 1. Mustard seed meal applied at a rate of $450 \mathrm{~g} \cdot \mathrm{m}^{-2}$ to grass seedlings.

ity is limited. Transportation of MSM from oil-crushing facilities to end users would be a major factor influencing the overall cost of MSM. Corn gluten meal has been used as an alternative to synthetic herbicides in turf but has not been widely used in many other settings as a result of inconsistent performance, increased rates required compared with use in turf, cost, and failure to control emerged weed seedlings. MSM appears to have some limited herbicidal effect on very small broadleaf weed seedlings (unpublished observations) and suppressed emerged liverwort in these studies.

MSM has potential to be developed as a selective herbicide for annual weed control in ornamental containers and further research could identify additional tolerant and susceptible species of both weeds and ornamentals.

\section{Literature Cited}

Al-Khatib, K. and R.A. Boydston. 1999. Weed control with Brassica green manure crops, p. 255-270. In: Narwal, S.S. (ed.). Allelopathy update, volume 2, basic and applied aspects. New Delhi, India: Oxford \& IBH Publishing Co. Pvt. Ltd. 
Ascard, J. and T. Johansson. 1991. White mustard meal interesting for weed control, p. 139-155. In: Weeds and weed control reports. 32nd Swedish Crop Protection Conference. Swedish University of Agricultural Sciences, Uppsala, Sweden.

Betz, J.M. and W.D. Fox. 1994. High-performance liquid chromatographic determination of glucosinolates in Brassica vegetables, p. 181-196. In: Food phytochemicals. I: Fruits and vegetables. ACS Symposium Series, American Chemical Society, Washington, DC.

Bingaman, B.R. and N.E. Christians. 1995. Greenhouse screening of corn gluten meal as a natural control product for broadleaf and grass weeds. HortScience 30:1256-1259.

Borek, V. and M.J. Morra. 2005. Ionic thiocyanate $\left(\mathrm{SCN}^{-}\right)$production from 4-hydroxybenzyl glucosinolate contained in Sinapis alba seed meal. J. Agr. Food Chem. 47:3837-3842.

Boydston, R.A. and K. Al-Khatib. 2006. Utilizing brassica cover crops for weed suppression in annual cropping systems, p. 77-94. In: Singh, H.P., D.R. Batish, and R.K. Kohli (eds.). Handbook of sustainable weed management. Haworth Press, Binghamton, NY.

Boydston, R.A., S.F. Vaughn, and H.P. Collins. 2008. Response of weeds and ornamental plants to potting soil amended with dried distillers grains. HortScience 43:191-195.

Brown, P.C., M.J. Morra, J.P. McCaffrey, D.L. Auld, and L. Williams III. 1991. Allelochemicals produced during glucosinolate degradation in soil. J. Chem. Ecol. 17:2021-2034.

Brown, P.D. and M.J. Morra. 1995. Glucosinolatecontaining plant tissues as bioherbicides. J. Agr. Food Chem. 43:3070-3074.

Brown, J., M. Hamilton, J. Davis, D. Brown, and L. Seip. 2006. Herbicidal and crop phytotoxicity of Brassicaceae seed meals on strawberry transplants and established crops. Proc. Second Intl. Biofumigation Symp. Moscow, ID. 25-29 June. 13 Feb. 2008. <http://www.ag. uidaho.edu/biofumigation/abstractinfo asp? ID $=75>$.

Daxenbichler, M.E., G.F. Spencer, D.G. Carlson, G.B. Rose, A.M. Brinker, and R.G. Powell. 1991. Glucosinolate composition of seeds from 297 species of wild plants. Phytochemistry 30:2623-2638.

Drost, W.J., G. Rakow, and P. Raney. 1999. Inheritance of glucosinolate content in yellow mustard. Proc. 10th Intl. Rapeseed Conf., Canberra, Australia. 13 Feb. 2008. <http://www. regional.org.au/au/gcirc/4/76.htm $>$.

Earlywine, D., T. Teuton, J.C. Sorochan, B. Fresenburg, R. Smeda, and L. Sweets. 2007. Evaluation of yellow mustard seed meal for weed control. ASA, CSSA, and SSSA International Meetings, New Orleans. 13 Feb. 2008. <http://a-c-s confex.com/a-c-s/2007am/techprogram/P36683. HTM>.

Liu, D.L., N.E. Christians, and J.T. Garbutt. 1994 Herbicidal activity of a hydrolyzed corn gluten meal on three grass species under controlled environments. J. Plant Growth Regul. 13:221226.

Liu, D.L. and N.E. Christians. 1997. The use of hydrolyzed corn gluten meal as a natural preemergence weed control in turf. International Turfgrass Society J. 8:1043-1050.

McDade, M.C. and N.E. Christians. 2001. Corn gluten hydrolysate for crabgrass (Digitaria spp.) control in turf. International Turfgrass Society J. 9:3-7.

Miller, T.W. 2006. Natural herbicides and amendments for organic weed control, p. 174-175. In: Felsot, A.S. and K.D. Racke (eds.). Crop protection products for organic agriculture. ACS
Symposium Series 947. American Chemical Society, Washington, DC.

Nonnecke, G.R. and N.E. Christians. 1993. Evaluation of corn gluten meal as a natural, weed control product in strawberry. Acta Hort. 348: 315-320.

Oleszek, W. 1987. Allelopathic effects of volatiles from some Cruciferae species on lettuce, barnyard grass and wheat growth. Plant Soil 102:271-274.

Oleszek, W., J. Ascard, and H. Johansson. 1994. Cruciferae as alternative plants for weed control in sustainable agriculture, p. 160. In: Narwal, S.S., P. Tauro, G.S. Dhaliwal, and J. Prakash (eds.). Abstract Book from the International Symposium 'Allelopathy in Sustainable Agriculture, Forestry and Environment.' Indian Society of Allelopathy, New Delhi, India.

Rice, A.R., J.L. Johnson-Maynard, D.C. Thill, and M.J. Morra. 2007. Vegetable crop emergence and weed control following amendment with different Brassicaceae seed meals. Renewable Agriculture and Food Systems 22:204-212.

Svenson, S. and W. Deuel. 2000. Using quinoclamine and meadowfoam seed meal to control liverworts in containers. Proc. SNA Res. Conf. 45:391-393.

Vaughn, S.F. and M.A. Berhow. 2005. Glucosinolate hydrolysis products from various plant sources: $\mathrm{pH}$ effects, isolation and purification. Ind. Crops Prod. 21:193-202.

Vaughn, S.F. and R.A. Boydston. 1997. Volatile allelochemicals released by crucifer green manures. J. Chem. Ecol. 23:2107-2115.

Vaughn, S.F., R.A. Boydston, and C. MallorySmith. 1996. Isolation and identification of (3-methoxyphenyl) acetonitrile as a phytotoxin from meadowfoam (Limnanthes alba) seedmeal. J. Chem. Ecol. 22:1939-1949. 